\title{
Dynamics of vitamin D in patients with mild or inactive inflammatory bowel disease and their families
}

\author{
Avigyle Grunbaum ${ }^{1}$, Christina Holcroft ${ }^{2}$, Debra Heilpern ${ }^{1}$, Stephanie Gladman ${ }^{3}$, Barry Burstein ${ }^{4}$, Maryse Menard $^{3}$, \\ Jasim Al-Abbad ${ }^{6}$, Jamie Cassoff', Elizabeth MacNamara ${ }^{5}$, Philip H Gordon ${ }^{6}$ and Andrew Szilagyi ${ }^{3^{*}}$
}

\begin{abstract}
Background: $25(\mathrm{OH})$ vitamin D levels may be low in patients with moderately or severely active inflammatory bowel diseases (IBD: Crohn's disease and Idiopathic Ulcerative Colitis) but this is less clear in patients with mild or inactive IBD. Furthermore there is limited information of any family influence on $25(\mathrm{OH})$ vitamin $\mathrm{D}$ levels in IBD. As a possible risk factor we hypothesize that vitamin $\mathrm{D}$ levels may also be low in families of IBD patients.

Objectives: To evaluate $25[\mathrm{OH}]$ vitamin D levels in patients with IBD in remission or with mild activity. A second objective is to evaluate whether there are relationships within IBD family units of $25[\mathrm{OH}]$ vitamin $\mathrm{D}$ and what are the influences associated with these levels.

Methods: Participants underwent medical history, physical examination and a 114 item diet questionnaire. Serum $25[\mathrm{OH}]$ vitamin $\mathrm{D}$ was measured, using a radioimmunoassay kit, (replete $\geq 75$, insufficient $50-74$, deficient $<25-50$, or severely deficient $<25 \mathrm{nmol} / \mathrm{L}$ ). Associations between $25[\mathrm{OH}]$ vitamin $D$ and twenty variables were evaluated using univariate regression. Multivariable analysis was also applied and intrafamilial dynamics were assessed.

Results: 55 patients and 48 controls with their respective families participated (N206). 25[OH] vitamin D levels between patients and controls were similar (71.2 $\pm 32.8 \mathrm{vs}$. $68.3 \pm 26.2 \mathrm{nmol} / \mathrm{L})$. Vitamin $D$ supplements significantly increased intake but correlation with serum $25[\mathrm{OH}]$ vitamin $D$ was significant only during non sunny months among patients. Within family units, patients' families had mean replete levels $(82.3 \pm 34.2 \mathrm{nmol} / \mathrm{L})$ and a modest correlation emerged during sunny months between patients and family $\left(r^{2}=0.209 p=0.032\right)$. These relationships were less robust and non significant in controls and their families.
\end{abstract}

Conclusions: In patients with mild or inactive IBD 25[OH] vitamin D levels are less than ideal but are similar to controls. Taken together collectively, the results of this study suggest that patient family dynamics may be different in IBD units from that in control family units. However contrary to the hypothesis, intra familial vitamin D dynamics do not pose additional risks for development of IBD.

Keywords: Vitamin D, Kinetics, Inflammatory bowel disease, Families

\section{Background}

The discovery of immunoregulatory and antineoplastic functions of vitamin $\mathrm{D}$ was followed by research to evaluate its possible pathogenic and therapeutic roles in multiple diseases [1-3]. Epidemiological and observational studies linked increased sunshine and ultraviolet light

\footnotetext{
* Correspondence: aszilagy@gas.jgh.mcgill.ca

${ }^{3}$ Gastroenterology, Jewish General Hospital, 3755 Cote Ste Catherine Rd, Room E177, Montreal, QC, Canada

Full list of author information is available at the end of the article
}

(UVB, $280-315 \mathrm{~nm}$ ) with diminished risks of many diseases [4-9] including general mortality [7].

The inflammatory bowel diseases (IBD: Crohn's Disease [CD] and Idiopathic Ulcerative Colitis [UC]) in particular have been noted to have distinct latitudinal distributions [10-12]. While pathogenesis of IBD remains elusive, environmental factors, the host's intestinal microbial flora and genetic immune modification putatively interact. Multiple predisposing genes, many overlapping between $\mathrm{CD}$ and UC have been described [13-15]. However, sunshine and UVB

\section{Biomed Central}


are hypothesized to have beneficial effects [2]. Both diseases have been associated with lower serum $25[\mathrm{OH}]$ vitamin D levels $[16,17]$ but the association is stronger with $C D$ [2,18-23]. Although, not yet proven two trials have been published using supplemental vitamin $\mathrm{D}$ for therapy of $\mathrm{CD}$ [24]. One suggested a possible reduction in clinical relapse [25]. Evaluation of $25[\mathrm{OH}]$ vitamin $\mathrm{D}$ levels in patients with moderate or severe IBD have shown low levels $[16,17]$ but mild or inactive IBD has been studied less frequently.

Vitamin D functions and levels have also been linked with genetic determinants. Vitamin D receptors (VDR) responsible for cell signaling in response to metabolites of vitamin D, have been found within several cell systems. These have been suggested to play a role in IBD [26-28]. In addition $25[\mathrm{OH}]$ vitamin $\mathrm{D}$ levels also relate to genetic polymorphisms controlling Vitamin D binding proteins (VDBP) $[29,30]$. These studies raise questions about possible genetic links determining serum $25[\mathrm{OH}]$ vitamin D levels within families. However, there have been limited reports evaluating intrafamilial relationships of 25 $[\mathrm{OH}]$ vitamin D levels. An early study from Manitoba in Canada found poor diet led to low $25(\mathrm{OH})$ vitamin D levels in mothers and infants [31]. Similarly a study from Jordan reported low 25(OH) vitamin D levels in both rachitic infants and their mothers. In this case prolonged breast feeding, poor diet and/or low sun exposure were blamed for the observation [32]. These studies suggest also that low family levels may be determined by environmental issues and may pose a risk for development of diseases.

The aims of this cross-sectional study were to compare serum $25[\mathrm{OH}]$ vitamin D levels in a cohort of IBD patients with mild or inactive disease to a cohort of healthy controls. Furthermore we compared these levels with a first degree family member and to make a second comparison between IBD families to healthy controls and their families. Common clinical variables were looked at and evaluated with respect to their association with levels of $25[\mathrm{OH}]$ vitamin D. We then evaluated the relationships of 25 $[\mathrm{OH}]$ vitamin D levels within both family units of IBD and controls. We hypothesized that low levels of vitamin D reported in IBD patients may be reflected in family members, thus constituting an additional family risk for IBD.

\section{Methods}

\section{Patients}

This study was carried out at the Jewish General Hospital from March 1, 2009 to April 30, 2011. Approval was obtained from the ethics and review board of the hospital. Patients were invited to participate and recruited from the department's IBD clinics as well as from gastroenterologists' practices. Each patient was asked to invite a first degree family member to be evaluated at the same time as the patients. Family members were self chosen by their availability for time to participate. Each participant gave informed signed consent. The diagnosis of Crohn's disease (CD) or ulcerative colitis (UC) was based on accepted criteria from previous evaluations (history, physical examination, radiology and/or histology) [33]. The recruited patients from clinics were stable (no change in medications for at least 3 months) and had mild or inactive disease). Each patient was assessed at entry into the study and was assigned a clinical index score based on well established criteria. In the case of $C D$, activity was assessed by the Harvey Bradshaw index [HBI] [34]. For UC the Simple Clinical Colitis Activity Index [SCCAI] was used [35]. In each case both the HBI and SCCAI, the score of $\leq 4$ indicates remission. Family members recruited were healthy or had stable (same definition as for stable patients) chronic diseases (hypertension, thyroid hormone replacement or hypercholesterolemia). However diabetes (types 1 and 2), known Celiac disease, other malabsorptive diseases or renal disease were excluded.

A control population was recruited by advertising for health care workers or other employees in the hospital, word of mouth or on university bulletin boards. These were recruited in groups following initial recruitment of patients. The controls were profiled to resemble patients with respect to age, sex, ethnicity and weight. First degree family members of controls (also self chosen by availability of time) were recruited with the same restriction as for patients' families. There was no attempt to profile family members of controls with family members of patients.

\section{Interventions}

\section{Clinical assessment}

Participants presented usually as a family unit on the day of the evaluation. All individuals underwent a brief history, physical examination including Body Mass Index (BMI: $\mathrm{Kg} / \mathrm{M}^{2}$ ) measurement and a series of blood tests for complete blood count, C-reactive protein, kidney function, biochemistry including calcium albumin and iron studies (ferritin and \% saturation). In addition serum vitamin 25 $(\mathrm{OH}) \mathrm{D}$ levels were measured.

\section{Dietary assessment}

After brief explanations, all participants completed a 114 item diet questionnaire This questionnaire was presented as a 5-page food frequency questionnaire (FFQ) which was developed and adapted from previously validated questionnaires. The FFQ is a general survey and is not dependent on specific time exposure to the foods. We used a diet limited FFQ to measure daily dietary calcium [87 items] [36], lactose [27 items] and vitamin D intakes [37]. Open-ended questions were included to identify potential contributors and nutrient interactions as dietary supplements and medications. Total daily intake of vitamin $\mathrm{D}$ and calcium included both within diet and supplements 
taken. The main source of vitamin $\mathrm{D}$, calcium and lactose are derived from dairy foods (mostly fluid milk). Lactose is a good surrogate for dairy foods as $12.5 \mathrm{~g}$ serving of lactose approximates the content of a $250 \mathrm{ml}$ volume of fluid milk.

Determination of portion sizes was done using 2dimension food models. A sample of any supplement was requested from participants. A systematic revision of each FFQ was performed by a dietician (SG and MM) and participants were contacted for any clarifications. Double-blinded data entry and analysis was performed using an Excel spreadsheet calculator. Nutrient values extracted from the Canadian Nutrient File 2007 [38] as well as the United States Dietary Association were used as references [39].

\section{Vitamin D measurements}

Serum $25[\mathrm{OH}]$ vitamin D was measured using an RIA kit as used in the hospital clinical chemistry unit (Immunodiagnostic Systems Ltd. IDS 10 Didcot Way Boldon Business Park, Boldon, Tyne and Wear NE35 9PD). The specificity is $100 \%$ for both 25 -Hydroxy Vitamin D3 and 24, 25 Hydroxyvitamin D3 and 75\% for 25 Hydroxy Vitamin D2.

The interassay precision at $58.7 \mathrm{nmol} / \mathrm{L}$ was SD -4.8 and CV of $8.2 \%$. Serum $25(\mathrm{OH})$ vitamin D levels were reported in $\mathrm{nmol} / \mathrm{L}$ and daily intake levels in International Units. The North American 25(OH) vitamin D level guidelines were used to classify patients into replete $\geq 75 \mathrm{nmol} / \mathrm{L}$, insufficient $50-74 \mathrm{nmol} / \mathrm{L}$, deficient $<50 \mathrm{nmol} / \mathrm{L}$ or severely deficient $<25 \mathrm{nmol} / \mathrm{L}[20,40]$.

Twenty variables were evaluated to determine univariate relationships to serum $25(\mathrm{OH})$ vitamin D levels. These variables included age, sex, BMI, race, ethnicity, smoking history, use of tanning salons (relevant in winter only), vacation 1 month prior to blood tests (relevant in winter only), total vitamin $\mathrm{D}$ intake, dietary and supplemental vitamin D intake, dairy food intake total calcium intake, dietary and supplemental calcium intake, disease versus no disease, corticosteroid intake, duration of disease, and in CD patients, whether colon or small bowel were affected. Additional effect of UVB was evaluated by assessing month of test and dividing time of testing either into sunny (May - September) or less sunny (October -April) months.

\section{Statistical analysis}

First, descriptive statistics (including means with standard deviations and proportions) were used to describe demographic characteristics, $25(\mathrm{OH})$ vitamin D serum levels, vitamin D and calcium intakes among patients, controls and their family groups Because these values were skewed in groups, some statistical comparisons were based on $\log 25(\mathrm{OH})$ vitamin $\mathrm{D}$ and were indicated as such. We used unpaired tests (two-sample $t$-test, chi-square test, or Fisher's exact test) to compare levels (i.e. serum 25(OH) vitamin $\mathrm{D}$ levels, vitamin $\mathrm{D}$ and calcium intakes) between patients and controls, and paired tests (paired $t$-test or McNemar's test for correlated proportions) between patients and their families, and between controls and their families, because we assumed that measured levels within family units were not independent. We then calculated correlations to examine the relationships accounting for seasons between vitamin $\mathrm{D}$ intake and $25(\mathrm{OH})$ vitamin D serum levels between patients and their family group and between controls and their family group, separately by different seasons. We used linear regression with log serum vitamin $25(\mathrm{OH}) \mathrm{D}$ as the outcome in univariate and multivariable analysis in order to identify variables that were significantly associated with serum $25(\mathrm{OH})$ vitamin $D$ levels. Regression analyses were conducted only among the combined sample of patients and controls, because these individuals were considered independent of one another. Finally, we examined and graphed the correlations of log serum vitamin $25(\mathrm{OH}) \mathrm{D}$ between patients and family, and between controls and family, separately by seasons.

All tests were two-tailed and statistical significance was accepted at $\mathrm{p} \leq 0.05$. Analyses were conducted using Stata statistical software (version 8.2, StataCorp, College Station, TX).

\section{Results}

\section{Participant demographics}

A total of 244 people were approached over the 25 month period. All participants lived in Montreal and usually within the same geographic area. Of these 38 were excluded from analysis because they did not meet criteria as described above. Two hundred and six participants remained to be analyzed. Within another 13 participants (6\%) 25(OH) vitamin D levels were inadvertently missing and are outlined in tables, leaving 193 for $25(\mathrm{OH})$ vitamin D analyses. When possible participants with missing levels were still included for assessment of dietary intakes.

After excluding individuals from the study there remained, 55 patients (21 UC and $34 \mathrm{CD}$ ) along with 55 first degree family members and 48 controls together with 48 of their family members. The distribution of family members were as follows: IBD relative family members, mothers $42.6 \%$,daughters $18.5 \%$, sisters $16.7 \%$, and fathers, brothers, sons each $7.3 \%$. Control family members were daughters $29 \%$, sons $23 \%$, mothers $17 \%$, sisters $16.7 \%$, brothers $8 \%$, fathers $6.3 \%$. Demographics of IBD patients are described in Table 1 . The majority were female with no significant difference in age between $\mathrm{CD}$ and UC patients. The majority in each IBD group were in remission with a mean HBI score of $2.6 \pm 1.9$ for CD and SCCAI of $2 \pm 1.3$ for UC. In the CD group however, 7 patients had a mean HBI score of 5.7 indicating mild activity (this represents $20.6 \%$ of the CD group and $12.7 \%$ of the entire group). 
Table 1 Demographics Counts (\%) are reported unless otherwise noted

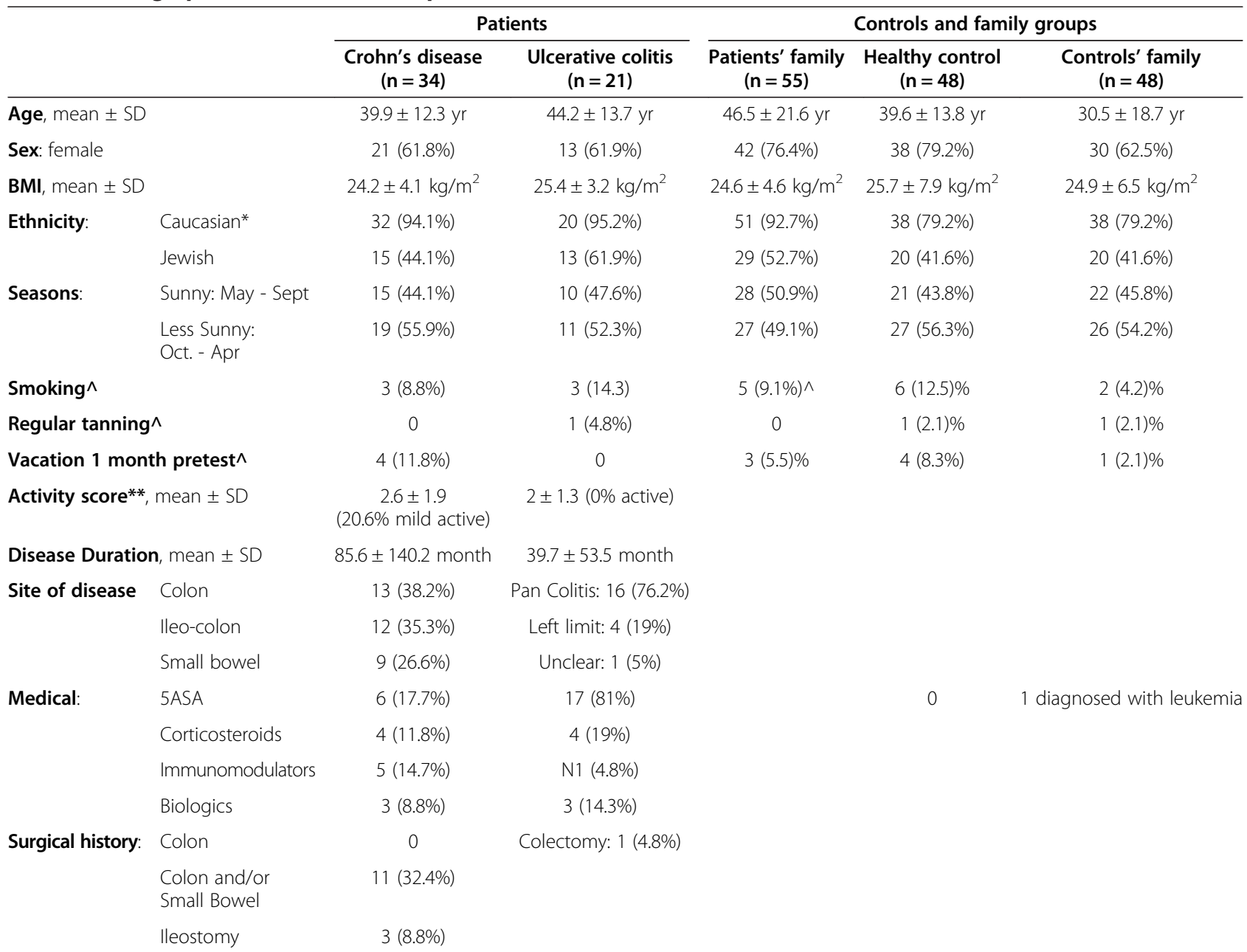

* Chi-square comparison of Caucasian in Patient vs. Controls yields $p=0.019$.

$\wedge$ Missing information on participants ranged from 25-50\%.

* Score for Crohn's based on Harvey Bradshaw Index [34] Inactive $\leq 4$

Score for Ulcerative Colitis based on Simple Clinical Colitis activity Index [35]. Inactive $<4$.

Correlation of HBI with serum $25(\mathrm{OH})$ vitamin $\mathrm{D}$ did show a modest inverse correlation $\left(r^{2}=0.057, r=-0.24\right)$ [data not shown]. These 7 also had elevations of CRP. None of the UC patients demonstrated activity by scores, although 4 had elevated CRP. CRP levels did not correlate well in 10 patients with available serum $25(\mathrm{OH})$ vitamin $\mathrm{D}$ levels [ $\mathrm{n}=10$ patients], $\left(\mathrm{r}^{2}=0.001, \mathrm{r}=0.029\right)$ [data not shown].

More than half of the patients were Jewish and only $6 \%$ were non Caucasians. The CD patients had their disease twice as long as the UC patients. The distribution of $\mathrm{CD}$ was mainly colon or colon and terminal ileum. None had gastric or duodenal disease based on current history and previous endoscopy or radiological assessment. Of the UC patients $75 \%$ had pancolitis and the others had left sided disease only. As expected 5-Amino Salicylic Acid (5ASA) use was common in UC but less than $20 \%$ in CD. Immunomodulators and biologics were used in a minority of patients. In the $\mathrm{CD}$ group 14 patients underwent at least one previous operation. One patient with UC had a remote colectomy. Table 1 outlines the demographics of families of IBD patients, controls and their families. Similar to the patient's group the majority of family members were female and there was no significant age difference from patients. Family members of patients were a decade older than family members of controls. Two controls and 2 family members of controls had CRP elevations. Non Caucasians were unevenly distributed in the groups (patients 3/55 [5.5\%] and controls 10/48 [20.8\%] respectively (Fisher's $\mathrm{p}=0.034$ ).

\section{Dynamics of vitamin $D$ in groups}

\section{Serum $25(\mathrm{OH})$ vitamin $D$ levels across 4 study groups}

The results of measured $25(\mathrm{OH})$ vitamin D levels and their distributional rank criteria as described in the method section are shown in Table 2. There was no significant difference in levels or distribution of vitamin D 
Table 2 Serum 25[OH] vitamin D by Groups

\begin{tabular}{|c|c|c|c|c|}
\hline Group* & $\begin{array}{c}\text { Serum Vit } 25(\mathrm{OH}) \mathrm{D} \\
\text { mean } \pm \mathrm{SD}\end{array}$ & $\begin{array}{c}\text { Replete: } \geq 75 \\
\text { n (\%) }\end{array}$ & $\begin{array}{c}\text { Insufficient: } 50-74 \\
\text { n (\%) }\end{array}$ & $\begin{array}{c}\text { Deficient: }<50 \\
\text { n (\%) }\end{array}$ \\
\hline \multirow[t]{2}{*}{ IBD Patients } & $71.2 \pm 32.8^{* *}$ & $21(38.2 \%)$ & $12(21.8 \%)$ & 17 (30.9\%) \\
\hline & & 15(71.4\%) & $3(25 \%)$ & $8(47.1 \%)$ \\
\hline \multirow[t]{2}{*}{ Crohn's Disease } & $71.1 \pm 31.1$ & $14(41.2 \%)$ & 7 (20.6\%) & $10(29.4 \%)$ \\
\hline & & $9(64.3 \%)$ & $2(28.6 \%)$ & $5(50 \%)$ \\
\hline \multirow[t]{2}{*}{ Ulcerative Colitis } & $71.4 \pm 36.3$ & 7 (33.3\%) & $5(23.8 \%)$ & 7 (33.3\%) \\
\hline & & $6(85.7 \%)$ & $1(20 \%)$ & $3(42.9 \%)$ \\
\hline \multirow[t]{2}{*}{ Patients' Family } & $82.3 \pm 34.2$ & $27(49.1 \%)$ & 18 (32.7\%) & 7 (12.7\%) \\
\hline & & $13(48.2 \%)$ & $5(27.8 \%)$ & 1 (14.3\%) \\
\hline \multirow[t]{2}{*}{ Healthy Control } & $68.3 \pm 26.2$ & 15 (31.3\%) & 19 (39.6\%) & $11(22.9 \%)$ \\
\hline & & 7 (46.7\%) & 11 (57.9\%) & $4(36.4 \%)$ \\
\hline \multirow[t]{2}{*}{ Controls' Family } & $69.9 \pm 27.6$ & 19 (39.6\%) & 16 (33.3\%) & $11(22.9 \%)$ \\
\hline & & 8 (88.9\%) & $5(31.3 \%)$ & $1(9.1 \%)$ \\
\hline
\end{tabular}

Levels and categories of serum $25[\mathrm{OH}]$ vitamin $\mathrm{D}$ in $\mathrm{nmol} / \mathrm{L}$ overall and by patient, control and their respective families are shown. The lower values represent the number of participants in each category who consumed supplemental vitamin $D$ and the percentage of the category in each group. Based on ( $n=193$ ) available serum levels.

* Because of some missing data on serum $25[\mathrm{OH}]$ vitamin D levels, percentages do not sum to $100 \%$. Missing data were as follows:

5 from IBD.

3 from Family IBD.

3 from Control.

2 from Family Control.

** patient vs. family: $\mathrm{p}=0.0332$ (paired $t$ test) or $\mathrm{p}=0.0164$ (for log values).

classifications between $\mathrm{CD}$ and UC patients or between IBD group and controls. One patient with UC had a level of $25(\mathrm{OH})$ vitamin $\mathrm{D}<25 \mathrm{nmol} / \mathrm{L}$ (severe deficiency). The mean serum $25(\mathrm{OH})$ vitamin D levels in the IBD family group was significantly higher than patients', using paired $t$ test for both actual and log values.

Association of vitamin $D$ intake, calcium intake, and season with serum $25(\mathrm{OH})$ vitamin $D$ levels

Description of daily vitamin D (total $=$ dietary + supplements) and calcium (total $=$ dietary + supplements) intake in the four groups is shown in Table 3. The number of participants who consumed vitamin D supplements in each study group is also reported. Controls consumed more daily vitamin $\mathrm{D}$, without statistically significant differences in intake between patients and controls. However, supplemental vitamin D daily intake significantly increased intake, to a range of $1100-1350$ (Table 3). Although higher than the RDA, these do not approach the tolerable upper limit (UL) for vitamin D of 4000 IU for children $>9$ yrs. and adults. Patients and controls had similar frequency of supplementary intake of vitamin D: patients: $53 \%$, IBD family: $36 \%$, healthy controls: $48 \%$, controls family: $31 \%$.

Table 4 contains average serum $25[\mathrm{OH}]$ vitamin D levels across categories of vitamin $\mathrm{D}$ intake with and without supplements, and across seasons, for each study group. Frequency toward replete levels increased but statistical significance was achieved only in patients depending on analysis (mean $\pm \mathrm{SD}, \mathrm{p}=0.03$ or mean $\log$ vitamin $\mathrm{D}$, $\mathrm{p}=0.059)$.

Intake of calcium appeared to affect $25[\mathrm{OH}]$ vitamin D levels but this was evident mainly in controls (data not shown). Calcium supplements were used by $58 \%$ and $46 \%$ of patients and controls respectively (NS). Similarly controls consumed more calcium than IBD patients, but the difference was not statistically significant. Controls did consume about twice as much dairy foods as patients (lactose: Controls, 21.9 g/d, Patients, $11.7 \mathrm{~g} / \mathrm{d}, \mathrm{p}=0.01$ ).

Regarding seasons, serum 25[OH] vitamin D levels in patients only were significantly increased in sunny months May - September compared to less sunny months October - April (Table 4). Among patients and controls combined $(\mathrm{N} 95)$ the mean $25(\mathrm{OH})$ vitamin $\mathrm{D}$ level during sunny months.

(N42, May - September) was $76.1 \pm 30.1 \mathrm{nmol} / \mathrm{L}$ while during less sunny months (N53, October- April) the level was $64.8 \pm 28.7 \mathrm{nmol} / \mathrm{L}(\mathrm{p}=0.046$, for $\log 25$ $(\mathrm{OH})$ vitamin $\mathrm{D})$.

Similarly taking a sunny vacation one month prior to testing or using tanning salons resulted in higher levels but there were too few participants for meaningful statistical analysis.

Correlations between vitamin D intake and serum 25 $[\mathrm{OH}]$ vitamin D levels are shown in Figure 1a and $1 \mathrm{~b}$, separately by seasons and for each study group. It is noted that the association of vitamin D intake with serum levels was more evident during less sunny months and was more 
Table 3 Intake of total, dietary or supplemental vitamin D and calcium by groups

\begin{tabular}{|c|c|c|c|c|}
\hline & $\begin{array}{l}\text { IBD Patients } \\
\mathrm{N}=55\end{array}$ & $\begin{array}{l}\text { Patients' } \\
\text { family } N=55\end{array}$ & $\begin{array}{l}\text { Controls } \\
\mathrm{N}=48\end{array}$ & $\begin{array}{l}\text { Controls' } \\
\text { family } N=48\end{array}$ \\
\hline Dietary Vit $D$ intakes in each group, $n$ & 54 & 54 & 46 & 48 \\
\hline Mean \pm SD IU & $371 \pm 333$ & $527 \pm 803$ & $600 \pm 848$ & $666 \pm 592$ \\
\hline Median & 286 & 260 & 394 & 416 \\
\hline Total Vit D Intakes in each group, $n$ & 54 & 54 & 46 & 48 \\
\hline Mean \pm SD & $784.4 \pm 720$ & $761.3 \pm 881.6$ & $917 \pm 1028$ & $867 \pm 801$ \\
\hline Median & 599.5 & 523 & 590.2 & 612. \\
\hline Total Vit D intakes in Subgroups with Supplemental Vit D, n & 29 & 20 & 23 & 15 \\
\hline Mean \pm SD & $1110 \pm 780^{*}$ & $1116.2 \pm 809.7^{* *}$ & $1279 \pm 857^{* *}$ & $1344.9 \pm 994.2^{* *}$ \\
\hline Median & 932.4 & 932.8 & 1020.8 & 1191.1 \\
\hline Total Vit D intakes in Subgroups without Supplemental Vit D, n & 23 & 34 & 23 & 32 \\
\hline Mean \pm SD & $404.2 \pm 409.2$ & $552.5 \pm 865.8$ & $554.3 \pm 1074.4$ & $648.4 \pm 605.3$ \\
\hline Median & 332.8 & 291.7 & 290.4 & 377.4 \\
\hline Total Calcium Intakes in each group, $\mathbf{n}$ & 54 & 54 & 46 & 48 \\
\hline Mean \pm SD & $1537.2 \pm 755$ & $1687.4 \pm 1071.5$ & $1778.7 \pm 1127.2$ & $1931.4 \pm 1325.6$ \\
\hline Median & 1479 & 1404.7 & 1552.1 & 1679.5 \\
\hline
\end{tabular}

Vitamin D intake is listed in International Units (conversion to $\mu \mathrm{g}$ is IU/40). Total daily calcium is listed as g/day. Vitamin D intakes were skewed and therefore both mean \pm standard deviation and median values are listed. $\mathrm{N}$ values for each group represents original number in the groups and $\mathrm{n}$ values actual numbers analyzed.

Comparisons of means of groups with and without vitamin D supplements were significant; ${ }^{*} p<0.01,{ }^{* *} p<0.05$.

robust in patients $\left(\mathrm{r}^{2}=0.315, \mathrm{r}=0.56, \mathrm{p}=0.003\right)$ than in controls $\left(r^{2}=0.13, r=0.36, p=0.07\right)$. There was no discernable effect of vitamin $\mathrm{D}$ intake by seasons in either family group.

\section{Univariate and multivariable analyses for serum $25(\mathrm{OH})$ vitamin $D$ in patients and controls combined}

We analyzed 20 individual variables as described in the methods section for univariate association with log serum $25(\mathrm{OH})$ vitamin D levels. Since there were no significant differences in $25(\mathrm{OH})$ vitamin D levels between patients and controls, these groups were combined for analyses. Five variables were statistically significant: Jewish ethnicity, vacation one month prior to study testing, total calcium intake, dietary (but not supplemental) calcium, and seasonal measurement of levels. Five other variables reached marginal significance $(\mathrm{p}<0.1)$. These were total vitamin $\mathrm{D}$ intake, Caucasian race, BMI, dietary (but not supplemental) vitamin $\mathrm{D}$, and use of corticosteroids by patients.

Table 4 Serum 25[OH] vitamin D according to intakes of vitamin D

\begin{tabular}{|c|c|c|c|c|}
\hline Item & $\begin{array}{l}\text { IBD Patients } \\
\mathrm{N}=55\end{array}$ & $\begin{array}{l}\text { Patients' } \\
\text { Family } \mathrm{N}=55\end{array}$ & $\begin{array}{l}\text { Controls } \\
\mathrm{N}=48\end{array}$ & $\begin{array}{l}\text { Controls' } \\
\text { Family N }=48\end{array}$ \\
\hline 25(OH)D levels in Supplement users, $n$ & 26 & 19 & 22 & 14 \\
\hline Mean $\pm \mathrm{SD}$ & $79.8 \pm 36.5^{*}$ & $86.7 \pm 24.1$ & $70.2 \pm 26.5$ & $74.6 \pm 15.9$ \\
\hline 25(OH)D levels in non Supplement users, $n$ & 21 & 32 & 22 & 31 \\
\hline Mean \pm SD & $59.4 \pm 25.0$ & $79.9 \pm 39.6$ & $67.9 \pm 26.1$ & $68.2 \pm 31.8$ \\
\hline \multicolumn{5}{|l|}{ Seasons: } \\
\hline May-Sept, n & 23 & 27 & 19 & 21 \\
\hline Mean $\pm \mathrm{SD}$ & $81.6 \pm 32.5 * *$ & $83.7 \pm 32.1$ & $69.5 \pm 26.3$ & $73.3 \pm 30.9$ \\
\hline Oct-April, n & 27 & 25 & 26 & 25 \\
\hline Mean $\pm S D$ & $62.4 \pm 31.0$ & $80.8 \pm 36.9$ & $67.4 \pm 26.6$ & $67.1 \pm 24.7$ \\
\hline
\end{tabular}

The effects of vitamin $D$ intake on $25[\mathrm{OH}]$ vitamin $\mathrm{D}$ with or without supplement or seasons of testing are shown for four groups. All serum $25[\mathrm{OH}]$ vitamin $\mathrm{D}$ levels are reported as nmol/L. May -Sept are sunny months, October -April are non sunny months. $\mathrm{N}$ values for each group represents original number in the groups and $n$ values actual numbers analyzed.

* The comparison of means \pm SD was significant ( $p=0.03$ compared with patients not taking vitamin $D$ supplements). However comparing log $25[0 H]$ vitamin $D$ the result became nonsignifcant $(p=0.059)$.

** $p=0.039$ compared with patients evaluated in October to April. 


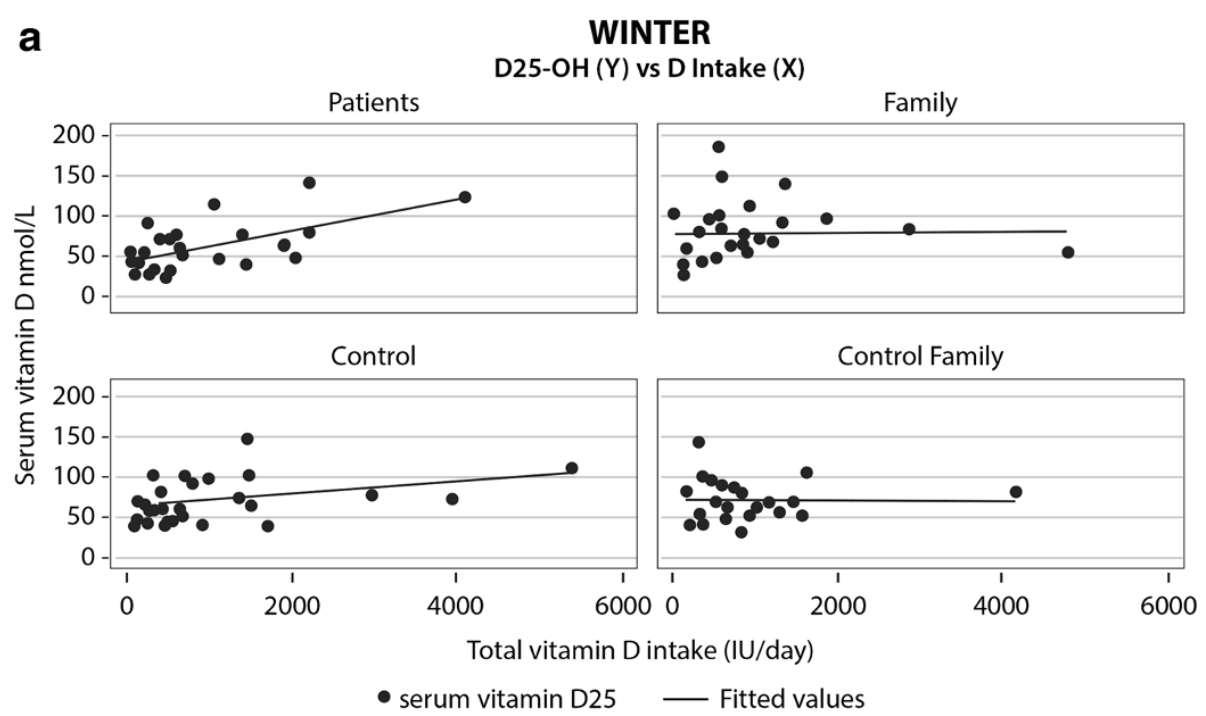

b

SUMMER

D25-OH (Y) vs D Intake (X)

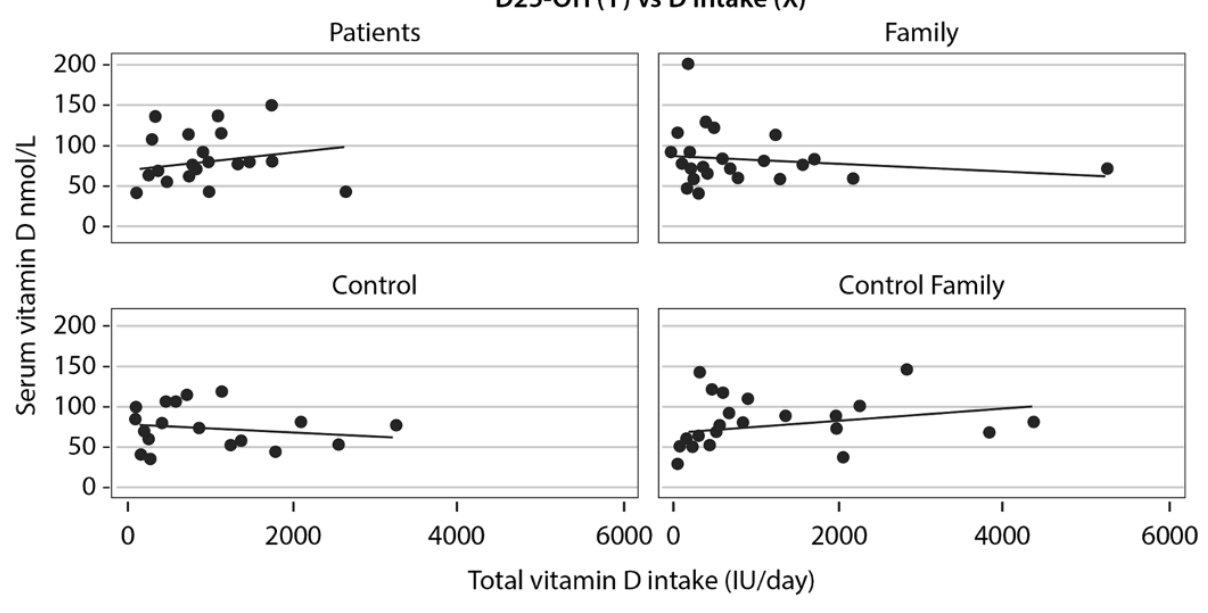

- serum vitamin D25 — Fitted values

Figure $125[\mathrm{OH}]$ vitamin $D$ levels and the effect of intake in groups by seasons. a. Winter: Patients $(N 26)\left(r^{2}=0.315, r=0.561, p=0.003\right)$, Families of patients (N25) $\left(r^{2}<0.001, r=0.003, p=0.990\right)$, Controls (N26) $\left(r^{2}=0.129, r=0.359, p=0.072\right)$ and Families of controls (N25) ( $r^{2}<0.001$, $r=0.010, p=0.961)$. b. Summer: Patients $(N=23):\left(r^{2}=0.036, r=0.191, p=0.384\right)$, Families of patients $(N 26):\left(r^{2}=0.024, r=-0.156, p=0.448\right)$, Controls (N18): $\left(r^{2}=0.018, r=-0.134, p=0.597\right)$ and Families of controls (N21): $\left(r^{2}=0.092, r=0.303, p=0.182\right)$.

Caucasians had higher serum 25[OH] vitamin D levels than non Caucasians in both patients and controls [Caucasian patients vs. non-Caucasian patients: $71.7 \pm 33.6$ vs. $64 \pm 18 \mathrm{nmol} / \mathrm{L}$ respectively] [Caucasian controls vs. non-Caucasian controls: $72.3 \pm 22.8$ vs. $54.5 \pm 33.3 \mathrm{nmol} / \mathrm{L}$ respectively]. In IBD and family groups only 3 non Caucasians were included contributing little to mean values of serum vitamin D. In the control group, 10 participants and 9 participants in their family group were non Caucasians. Comparison of mean levels of 25[OH] vitamin $\mathrm{D}$ for Caucasians versus non Caucasians was of borderline significance in the controls $(\mathrm{p}=0.0575)$ but was more substantial in the control family $(\mathrm{p}=0.003)$. Exclusion of all non Caucasians did raise the mean $25[\mathrm{OH}]$ vitamin D level to $75.6 \mathrm{ng} / \mathrm{L}$ ). Comparison of means in Caucasian patients with Caucasian controls after removal of non Caucasians still showed no significant differences [71.7 \pm 33.6 vs. $72.3 \pm 22.8$ (SD) nmol/L respectively NS].

In multivariable analysis seasonal testing, Jewish ethnicity, intake of dietary calcium and intake of total vitamin D remained in the model $(n=91)$.

\section{Dynamics of Vitamin D within family units}

Overall there was a modest non significant correlation in $\log 25[\mathrm{OH}]$ vitamin D levels within families (patients and family $\mathrm{r}^{2}=0.06, \mathrm{r}=0.24 ; \mathrm{p}=0.1$ control and family 
$\left.r^{2}=0.08, r=0.29 ; p=0.06\right)$. When family units were separated by sunny or less sunny season of testing, the levels of log values between patients and their families became statistically significant $\left(r^{2}=0.209, r=0.46, p=0.032\right.$ in sunny months vs $\mathrm{r}^{2}=0.0672, \mathrm{r}=0.26, \mathrm{p}=0.244$ less sunny months) (Figure $2 \mathrm{a}$ and $2 \mathrm{c}$ respectively). This altered relationship was weaker between controls and their families $\left(\mathrm{r}^{2}=0.197, \mathrm{r}=0.44, \mathrm{p}=0.065\right.$ more sunny months, $\mathrm{r}^{2}=0.007, \mathrm{r}=0.08, \mathrm{p}=0.695$ less sunny months) (Figure $2 \mathrm{~b}$ and $2 \mathrm{~d})$.

Among the four groups, IBD family members had the highest mean replete $25[\mathrm{OH}]$ vitamin $\mathrm{D}$ levels $(82.3 \pm 34.2 \mathrm{nmol} / \mathrm{L})$ and highest frequency in this category (49.1\%, Table 2).

Comparison of the distribution of deficiency categories was not significantly different between patient and controls (chi-square $\mathrm{p}=0.164$ ), but was significantly different between IBD patients and their family members (McNemar's $\mathrm{p}=0.0102$ ), indicating a more deficient state in the patients.

\section{Discussion}

The main outcomes of this study are as follows. Firstly, approximately $2 / 3$ of individuals within the group of IBD patients with mild or inactive disease have insufficient or deficient $25[\mathrm{OH}]$ vitamin D levels. However this is similar to that found in healthy controls. We confirm seasonal variation in $25[\mathrm{OH}]$ vitamin D levels. Measurement of serum $25[\mathrm{OH}]$ vitamin D during sunny months significantly affected patients levels. Overall consumption of vitamin D supplements increased patient's serum levels (marginal statistical significance). Families of patients or controls and their families appeared to be less affected by these variables. The IBD families as a group, show higher mean $25(\mathrm{OH})$ vitamin $\mathrm{D}$ level and more often achieve replete status than patients. A modest but significant relationship with patients' levels becomes evident during sunny months.

Our definitions of the distributions for $25[\mathrm{OH}]$ vitamin $\mathrm{D}$ have an influence over the proportion of replete and insufficient number in groups. The controversy over acceptable levels of $25[\mathrm{OH}]$ vitamin D continue and are accentuated by the recent decision of the Institute of Medicine (IOM) to endorse the $50 \mathrm{nmol} / \mathrm{L}$ as optimal value for skeletal health [41]. If we accept the IOM definition, $2 / 3$ of patients and $3 / 4$ of controls remain replete. However, there is controversy whether levels of 25 $[\mathrm{OH}]$ vitamin $\mathrm{D}$ acceptable for skeletal health are also applicable to autoimmune or other diseases and the IOM decision was criticized [42]. Our hospital accepts $25[\mathrm{OH}]$ vitamin D distributions at the higher levels as defined herein. In this way about $60 \%$ of IBD patients and $2 / 3$ of controls remain insufficient. Other studies, including mostly active cases have reported lower levels in IBD $[16,17,20-22]$, but others do report results similar to our study $[43,44]$. In the current study, although only a
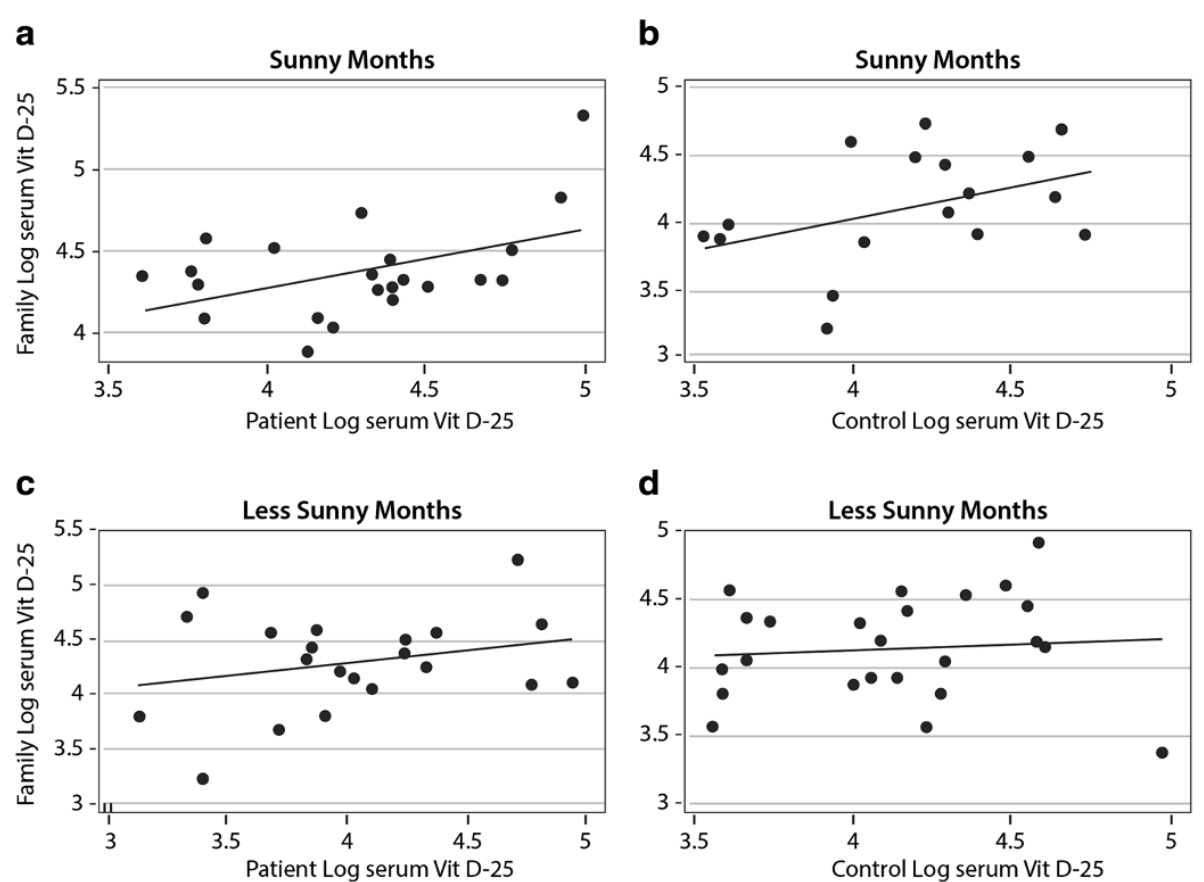

Figure 2 Relationships of serum $25[\mathrm{OH}]$ vitamin D levels within families by seasons. a. Correlations, slopes and $p$-values for plots of log serum VitD-25 of Patients vs. Families of patients in Summer $(N 22)\left(r^{2}=0.2098, r=0.458, p=0.032\right): \mathbf{b}$ winter $(N 22)\left(r^{2}=0.0672, r=0.259, p=0.24\right)$, c Controls vs. Families of controls in summer (N18) $\left(r^{2}=0.1969, r=0.444, p=0.065\right)$, $\mathbf{d}$ in winter $(N 25)\left(r^{2}=0.0068, r=0.082, p=0.6955\right)$. 
few patients with CD had modestly elevated HBI scores, there was a weak inverse correlation with serum $25(\mathrm{OH})$ vitamin D levels, suggesting that perhaps active disease is the cause (or effect of) lower serum $25(\mathrm{OH})$ vitamin D in such cases.

\section{The impact of seasons and vitamin D intake}

Evaluating the most relevant variables affecting serum 25 $[\mathrm{OH}]$ vitamin D levels, MVA ranked sunshine as the most influential on serum levels. The effect of seasons on serum $25[\mathrm{OH}]$ vitamin D has been previously described [22]. Seasonal variation altered serum levels and the effect of vitamin $\mathrm{D}$ intake on levels. The effects were more evident in patients as sunshine compensated for intake in sunny months while vitamin D intake affected $25[\mathrm{OH}]$ vitamin D levels in non sunny months. Still these effects did not as a whole compensate enough to achieve uniform replete levels.

In the current study patients who consumed vitamin D supplements had higher levels than those who relied solely on diet, but levels still did not reach desired values. About half the patients and controls consumed supplements but almost $60 \%$ did not achieve replete levels. Nevertheless the intake of supplements was disappointing. Only in the patient's group was there an apparent important increase in levels seconday in vitamin D supplemental intake but did not reach conventional statistical significance. The explanation for the effect on patients is not clear, especially in the light of a recent finding that at least CD patients may have a $35 \%$ less efficiency in absorption of vitamin D [45].

Therefore, larger quantities of vitamin D intake may be needed in general and in winter in particular. At least $1200 \mathrm{IU} / \mathrm{d}(15 \mu \mathrm{g})$ is required for replete levels [25]. However, Aloia suggested that $3200 \mathrm{IU} / \mathrm{d}$ should be used for at least 2 months and a simulated model found that $4600 \mathrm{IU} / \mathrm{d}$ consistently achieved the $75 \mathrm{nmol} / \mathrm{L}$ mark [40].

The MVA also ranked Jewish ethnicity and dietary calcium as important determinants of serum vitamin D levels in this study. As explained in the results Jewish ethnicity frequency was similar in both patients and control groups. Their serum $25[\mathrm{OH}]$ vitamin D levels were not significantly different from non Jewish groups but was more evident in the control group.

Dietary calcium was significantly related to serum vitamin D levels but a relationship was only observed in controls. The reason for this is not clear. It is possible that this variable reflected the increased dairy food consumption in controls with increased vitamin $\mathrm{D}$ added to such foods. Calcium intake can increase 25 $[\mathrm{OH}]$ vitamin D levels, when the source of both is from milk but not other sources [46].

\section{The impact of intrafamilial dynamics}

Contrary to our expectations IBD family members as a group had the highest rather than lowest mean $25[\mathrm{OH}]$ vitamin D levels. The levels in patient's families were significantly higher than those in patients. The difference between them was significantly greater than the difference noted between controls and their families. Furthermore a modest but significant correlation in the IBD family unit emerged during sunny months which was less evident in the control family unit.

The reason(s) for these findings is (are) not clear. The possibilities include chance, because of relatively few participants in each group. Our control group may not have been as healthy as expected. $25(\mathrm{OH})$ vitamin D results of current controls were however, similar to those reported by others $[43,44]$ and were similar to another healthy control group reported from Montreal [47].

The inclusion of more non Caucasians in the control groups may have limited the $25[\mathrm{OH}]$ vitamin D levels in the controls and their families. Non Caucasians may have lower 25[OH] vitamin D levels [48] However the numerical advantage of the IBD families was only modestly diminished by removal of the non Caucasians from controls. Furthermore the consistent relationships, observed in patients and the family unit rather than controls and their family unit, reduces somewhat the role of chance or the inclusion of excessive non Caucasians in the latter family unit. Still, it is possible that intra family dynamics are different between Caucasians and non Caucasians and this may have influenced intra family results.

In view of intra IBD family unit observations proposal of a genetic link unique to IBD patients and their families is tempting. However, failure to recruit both parents and inclusion of random single family members instead, dilutes ability to detect firm connections. Other undetected variables may also have contributed.

\section{Limitations of study}

Limitations in this study need to be considered. Firstly there are a paucity of participants and lack of homogeneity of the IBD group. The use of the combination of IBD patients rests on the similar $25[\mathrm{OH}]$ vitamin $\mathrm{D}$ levels found in both groups. A second limitation is the use of clinical indexes to define clinical status of patients. Although, well recognized as markers of activity the HBI or SCCI do not preclude false judgment of remission or activity. The presence of symptoms may indicate irritable bowel related symptoms or those secondary to previous surgery (eg. diarrhea). In conjunction with this notion is that we evaluated patient's status on a single blood test measurement, which does not allow any longitudinal assessment of clinical course. A third limitation is the absence of data in different categories. Most of these were inadvertent but data that were not available were not used to derive effects on serum vitamin D. In other situations however available data were used to answer questions pertaining to an outcome. For example intake of vitamin D was used to derive 
that particular information but was not used to relate to serum levels if those values were unavailable. Another limitation was in the way the data were analyzed (combination of patients and controls for effects of variables) may have precluded demonstration of disease effect on $25[\mathrm{OH}]$ vitamin D levels. With the exception of a weak impact of corticosteroids, none of the previously shown effects of IBD on $25[\mathrm{OH}]$ vitamin D levels were found $[20,49,50]$. However, the reason for lack of disease effect, may also relate to the clinical stability of our patients which mostly included inactive or mildly active disease. This suggests that disease activity is more likely an important determinant of serum $25[\mathrm{OH}]$ vitamin D.

\section{Conclusions}

We report on $25[\mathrm{OH}]$ vitamin D levels in a practical clinical setting for stable IBD patients predominantly in remission. Seasonal effects and the intake of vitamin D supplements appeared to be more evident in the IBD family unit largely driven by patients reactions.

Taken together this study suggests different vitamin D dynamics in patient's family units than in control's family units. The explanation for these observations is not evident from this study. However, it does suggest that further evaluation is needed to determine optimal vitamin $\mathrm{D}$ intake to uniformly achieve replete levels in IBD. Furthermore we demonstrate that IBD family vitamin D dynamics do not increase risk for these diseases. Further work would be needed to determine whether these dynamic differences can be reproduced.

\section{Abbreviations \\ IBD: Inflammatory bowel disease; CD: Crohn's disease; UC: Ulcerative colitis; UVB: Ultraviolet light B (280 - $315 \mathrm{~nm})$; BMI: Body mass index $\left(\mathrm{Kg} / \mathrm{m}^{2}\right)$; FFQ: Food frequency questionnaire; CV: Coefficient of variation; IOM: Institute of medicine; IU: International units; MVA: Multivariable analysis.}

\section{Competing interests}

The authors declare that they have no competing interests.

\section{Authors' contributions}

CH: Design of Statistical approach, analysis of data, writing of manuscript. AG: Carrying out clinical portions of the study, Data entry, and discussions about the topic, presentation of abstract ACG Washington, correction and approval of manuscript. $\mathrm{DH}, \mathrm{BB}, \mathrm{JC}$ and $\mathrm{JA}$; all participated in discussions of the topic, carrying out clinical portions of the study, data entry reviewed and approved the final manuscript. SG and MM: Design of diet questionnaires and pictures of portion sizes. Analysis of lactose, calcium and vitamin D content of intakes. Data entry and synthesis for statistical calculations. EM: responsible for serum vitamin $D$ analysis, discussions of the topic. Advice on aspects of writing the manuscript, review and approval of final manuscript. PHG: Discussions on design of the study, review of presentations at meetings and review and approval of final manuscript. AS: Design of study, Initiation of project. Writing of manuscript. All authors approve the final manuscript.

\section{Funding}

Department of Colorectal Surgery, Private donation funds Dr Szilagyi has served on Advisory Board meetings for Janssen Pharmaceuticals and Ferring Pharmaceuticals speaker for the Canadian Dairy Bureau

Dr Gordon had the following associations with companies:
Axcan Pharma Consultant

Bayer Healthcare Consultant

Cook Myosite Consultant

Nestle Honorarium

ProStrakan Pharmaceuticals Consultant

Sanofi-Aventis Speaker

Theramed Advisory Board

\section{Author details}

${ }^{1}$ McGill University School of Medicine, Montreal, Canada. ${ }^{2}$ Epidemiology, Jewish General Hospital, Montreal, Canada. ${ }^{3}$ Gastroenterology, Jewish General Hospital, 3755 Cote Ste Catherine Rd, Room E177, Montreal, QC, Canada. ${ }^{4}$ Department of Medicine, Jewish General Hospital, Montreal, Canada. ${ }^{5}$ Clinical Chemistry, Jewish General Hospital, Montreal, Canada. ${ }^{6}$ Colorectal Surgery, Jewish General Hospital, Montreal, QC, Canada.

Received: 26 May 2013 Accepted: 6 November 2013 Published: 9 November 2013

\section{References}

1. Zitterman $A$ : Vitamin $D$, in preventive medicine: are we ignoring the evidence? Br J Nutr 2003, 89:552-572. PMID:12720576.

2. Garg M, Lubel JS, Sparrow MP, Holt SG, Gibson PR: Review article: vitamin $\mathrm{D}$ and inflammatory bowel disease - established concepts and future directions. Aliment Pharmacol Therap 2012, 36:324-344. 10.1111/j.1365-2036.2012.05181.x.

3. Cantorna MT, Mahon BD: Mounting evidence for vitamin $\mathrm{D}$ as an environmental factor affecting autoimmune disease prevalence. Exp Biol Med (Maywood) 2004, 229:1136-1142. PMID:15564440.

4. Grant WB: A meta-analysis of second cancers after a diagnosis of non-melanoma skin cancer: additional evidence that solar ultraviolet $-B$ irradiance reduces the risk of internal cancers. J Steroid Biochem Mol Biol 2007, 103:668-674. PMID:17208438.

5. Tuohimaa P, Pukkala E, Scelo G, Olsen JH, Brewster DH, Hemminki K, Tracey E, Weiderpass E, Kliewer EV, Pompe-Kirn V, McBride ML, Martos C, Chia KS, Tonita JM, Jonasson JG, Boffetta P, Brennan P: Does solar exposure, as indicated by the non-melanoma skin cancers, protect from solid cancers: vitamin D as a possible explanation. Euro J Cancer 2007, 43:1701-1712. PMID: 17540555.

6. Grant WB: How strong is the evidence that solar ultraviolet $B$ and vitamin D reduces the risk of cancer. Dermatoendocrinol 2009, 1:17-24. PMID:20046584.

7. Holick MF: Vitamin D and sunlight: strategies for cancer prevention and other health benefits. Clin J Am Soc Nephrol 2008, 3:1548-1554. 10.2215/ CJN.01350308.

8. Garland CF, Gorham ED, Mohr SB, Garland FC: Vitamin D for cancer prevention: global perspective. Ann Epidemiol 2009, 19:468-483. 10.1016/j. annepidem.2009.03.021.

9. Zitterman A, lodice S, Pilz S, Grany WB, Bagnardi WB, Gandini S: Vitamin D deficiency and mortality risk in the general population: a meta-analysis of prospective cohort studies. Am J Clin Nutr 2012, 95:91-100. 10.3945/ ajcn.111.014779.

10. Peyrin-Biroulet I, Oussalah A, Bigard M-A: Crohn's disease: the hot hypothesis. Med Hypotheses 2009, 73:94-96. 10.1016/j.mehy.2009.01.022.

11. Sonnenberg A, McCarty DJ, Jacobsen SJ: Geographic variation of inflammatory bowel disease within the United States. Gastroenterology 1991, 100:143-149. PMID:1983816.

12. Shivananda S, Lennard-Jones J, Logan R, Logan R, Fear N, Price A, Carpenter $L$, van Blankenstein $M$ : Incidence of inflammatory bowel disease across Europe: is there a difference between north and south ? Results of the European collaborative study on inflammatory bowel disease (EC-IBD). Gut 1996, 39:690-697. PMID: 9014768.

13. Schirbel A, Fiocchi C: Inflammatory bowel disease: established and evolving considerations on its etiopathogenesis and therapy. J Dig Dis 2010, 11:266-276. 10.1111/j.1751-2980.2010.00449.x.

14. Abraham A, Cho JH: Inflammatory bowel disease. N Engl J Med 2009, 361:2066-2078. 10.1056/NEJMra0804647.

15. Jostins L, Ripke S, Weersma RK, Duerr RH, McGovern DP, Hui KY, Lee JC, Schumm LP, Sharma Y, Anderson CA, Essers J, Mitrovic M, Ning K, Cleynen I, Theatre E, Spain SL, Raychaudhuri S, Goyette P, Wei Z, Abraham C, Achkar JP, Ahmad T, Amininejad L, Ananthakrishnan AN, Andersen V, Andrews JM, 
Baidoo L, Balschun T, Bampton PA, Bitton A, et al: Letter: Host-microbe interactions have shaped the genetic architecture of inflammatory bowel disease. Nature 2012, 491:119-124. 10.1038/nature11582

16. Gilman J, Shanahan F, Cashman KD: Altered levels of biochemical indices of bone turnover and bone-related vitamins in patients with Crohn's disease and ulcerative colitis. Aliment Pharmacol Therap 2006, 23:1007-1016. PMID:16573803.

17. Miller HL, Farraye FA, Coukos J, Howard LA, Holick MF, Stucchi AF, Becker $J M$ : Vitamin D deficiency and insufficiency are common in ulcerative colitis patients after ileal pouch-anastomosis. Inflamm Bowel Dis 2013, 19:E25-E26. 10.1002/ibd.22890.

18. Ananathakrishnan AN, Khalili H, Higuchi LM, Bao Y, Korzenik JR, Giovannucci EL, Richter JM, Fuchs CS, Chan AT: Higher predicted vitamin D status is associated with reduced risk of Crohn's disease. Gastroenterology 2012 142:482-489. 10.1053/j.gastro.2011.11.040.

19. Nerich V, Jantchou P, Boutron-Ruault M-C, Monnet E, Weill A, Vanbockstael V, Auleley GR, Balaire C, Dubost P, Rican S, Allemand H, Carbonnel F: Low exposure to sunlight is a risk factor for Crohn's disease. Aliment Pharmacol Therap 2011, 33:940-945. 10.1111/j.1365-2036.2011.04601.x.

20. Ulitsky A, Ananthakrishnan AN, Naik A, Skaros S, Zadvornova Y, Binion DG, Issa M: Vitamin D deficiency in patients with inflammatory bowel disease: association with disease activity and quality of life. J Parent Ent Nutr 2011, 35:308-316. 10.1177/0148607110381267.

21. Pappa HM, Grand RJ, Gordon CM: Report on the vitamin D status of adult and pediatric patients with inflammatory bowel disease and its significance for bone health and disease. Inflamm Bowel Dis 2006, 12:1162-1174. PMID:17119391.

22. McCarthy D, Duggan P, O'Brien M, Kiely M, McCarthy J, Shanahan F, Cashman KD: Seasonality of vitamin D status and bone turnover in patients with Crohn's disease. Aliment Pharmacol Therap 2005, 21:1073-1083. PMID: 15854168

23. Siffledeen JS, Siminoski K, Steinhart H, Greenberg G, Fedorak RN: The frequency of vitamin $D$ deficiency in adults with Crohn's disease. Can J Gastroenterol 2003, 17:473-478. PMID:12945007.

24. Nicholson I, Dalzell AM, El-Matary W: Vitamin D as a therapy for colitis: a systematic review. J Crohn's Colitis. 2012, 6:405-411. 10.1016/j. crohns.2012.01.007.

25. Jorgensen SP, Agnholt J, Glerup H, Lyhne S, Villadsen GE, Hvas CL, Bartels LE, Kelsen J, Christensen LA, Dahlerup JF: Clinical trial: vitamin D3 treatment in Crohn's disease - a randomized double-blind placebo- controlled study. Aliment Pharmacol Therap 2010, 32:377-383. 10.1111/j.1365-2036.2010.04355.X

26. Simmons JD, Mullighan C, Welsh Kl, Jewell DP: Vitamin D receptor gene polymorphism: associated with Crohn's disease susceptibility. Gut 2000, 47:211-214. PMID:10896912.

27. Froicu M, Weaver V, Wynn TA, McDowell MA, Welsh JE, Cantorna MT: A crucial role for the vitamin D receptors in experimental inflammatory bowel diseases. Mol Endocrinol 2003, 17:2386-2392. PMID:14500760.

28. Xue LN, Xu KQ, Zhang W, Wang Q, Wu J, Wang XY: Associations between vitamin $D$ receptor polymorphisms and a susceptibility to ulcerative colitis and Crohn's disease: a meta- analysis. Inflamm Bowel Dis 2013, 19:54-60. 10.1002/ibd.22966.

29. Fu L, Yun F, Oczak M, Wong BYL, Vieth R, Cole DEC: Common genetic variants of the vitamin $D$ binding protein (DBP) predict differences in response of serum 25-hydroxyvitamin D [25(OH)D] to vitamin D supplementation. Clin Biochem 2009, 42:1174-1177. 10.1016/j. clinbiochem.2009.03.008

30. Wang TJ, Zhang F, Richards JB, Kestenbaum B, van Meurs JB, Berry D, Kiel DP, Streeten EA, Ohlsson C, Koller DL, Peltonen L, Cooper JD, O'Reilly PF, Houston DK, Glazer NL, Vandenput L, Peacock M, Shi J, Rivadeneira F, McCarthy MI, Anneli P, de Boer IH, Mangino M, Kato B, Smyth DJ, Booth SL, Jacques PF, Burke GL, Goodarzi M, Cheung CL, et al: Common genetic determinants of vitamin $D$ insufficiency: a genome -wide association study. Lancet 2010, 376:180-188. 10.1016/S0140-6736(10)60588-0.

31. Lebrun JB, Moffatt ME, Mundy RJ, Sangster RK, Postl BD, Dooley JP, Dilling LA, Godel JC, Haworth JC: Vitamin D deficiency in a Manitoba community. Can J Public Health 1993, 84:394-396. PMID: 8131142

32. Dawodu A, Agarwal M, Sankarankutty M, Hardy D, Kochiyil J, Badrinath P: Higher prevalence of vitamin D deficiency in mothers of rachitic than nonrachitic children. J Pediatr 2005, 147:109-111. PMID:16027707.

33. Lennard-Jones JE: Classification of inflammatory bowel disease. Scand J Gastroenterol Supp/ 1989, 170:2-6. PMID:2617184.
34. Harvey RF, Bradshaw JM: A simple index of Crohn's disease activity. Lancet 1980, 1(8178):1134-1135. PMID:6103463.

35. Walmsley RS, Ayres RCS, Pounder RE, Allan RN: A simple clinical colitis activity index. Gut 1998, 43:29-32. PMID:9771402.

36. Sebring NG, Denkinger BI, Menzie CM, Yanoff LB, Parikh SJ, Yanovski JA: Validation of three food frequency questionnaires to assess dietary calcium intake in adults. J Am Diet Assoc 2007, 107:752-759. PMID: 17467370 .

37. Cooper GS, Bushy MG, Fairchild AP: Measurement of lactose consumption reliability and comparison of two methods. Ann Epidemiol 1995, 5:473-477. PMID: 8680610

38. Canadian nutrient file; 2007. http://www.hc-sc.gc.ca/fn-an/nutrition/fiche-nutridata/ index_e.html (last accessed Oct 18/2013).

39. National nutrient database for standard reference. http://ndb.nal.usda.gov/ (last accessed Oct 18/2013).

40. Aloia JF, Patel M, DiMaano R, Li-Ng M, Talwar SA, Mikhail M, Pollack S, Yeh JK: Vitamin D intake to attain a desired serum 25-hydroxyvitamin D concentration. Am J Clin Nutr 2008, 87:1952-1958. PMID:18541590.

41. Ross AC, Manson JE, Abrams SA, Aloia JF, Brannon PM, Clinton SK, Durazo-Arvizu RA, Gallagher JC, Gallo RL, Jones G, Kovacs CS, Mayne ST, Rosen CJ, Shapses SA: The 2011 report on dietary reference intakes for calcium and vitamin D from the institute of medicine: what clinicians need to know. J Clin Endocrinol Metab 2011, 96:53-58. 10.1210/jc.2010-2704

42. Heaney RP, Holick MF: Why the IOM recommendations for vitamin D are deficient. J Bone Mineral Res 2011, 26:455-457. 10.1002/jbmr.328.

43. Abreu MT, Kantorovich V, Vasiliauskas EA, Gruntmanis U, Matuk R, Daigle K, Chen S, Zehnder D, Lin YC, Yang H, Hewison M, Adams JS: Measurement of vitamin $D$ levels in inflammatory bowel disease patients reveals a subset of Crohn's disease patients with elevated 1,25-dihydroxyvitamin D and low bone mineral density. Gut 2004, 53:1129-1136. PMID:15247180.

44. Hessov I, Mosekilde L, Melsen F. Fasth S, Hultén L, Lund B, Lund B, Sørensen $\mathrm{OH}$ : Osteopenia with normal vitamin D metabolites after small- bowel resection for Crohn's disease. Scand J Gastroenterol 1984, 19:691-696. PMID: 6332369.

45. Farraye FA, Nimitphong H, Stucchi A, Dendrinos K, Boulanger AB, Vijjeswarapu A, Tanennbaum A, Biancuzzo R, Chen TC, Holick MF: Use of a novel vitamin D bioavailability test demonstrates that vitamin $D$ absorption is decreased in patients with quiescent Crohn's disease. Inflamm Bowel Dis 2011, 17:2116-2121. 10.1002/ibd.21595.

46. Steingrimsdottir L, Gunnarsson O, Indridason OS, Franzson L, Sigurdsson G: Relationship between serum parathyroid hormone levels, vitamin D sufficiency, and calcium intake. J Am Med Asscn 2005, 294:2336-2341. PMID:16278362.

47. Zhang M, Robitaille L, Eintracht S, Hoffer $\sqcup$ : Vitamin C provision improves mood in acutely hospitalized patients. Nutrition 2011, 27:530-533. 10.1016/j.nut.2010.05.016

48. Y-Tn FU, Chatur N, Cheong-Lee C, Salh B: Hypovitaminosis D in adults with inflammatory bowel disease:potential role of ethnicity. Dig Dis Sci 2012, $57: 2144-2148$

49. Tajika M, Matsuura A, Nakamura T, Suzuki T, Sawaki A, Kato T, Hara K, Ookubo K, Yamao K, Kato M, Muto Y: Risk factors for vitamin D deficiency in patients with Crohn's disease. J Gastroenterol 2004, 39:527-533. PMID:15235869.

50. lijima $\mathrm{H}$, Shinzaki S, Takehara T: The importance of vitamins $\mathrm{D}$ and $\mathrm{K}$ for the bone health and immune function in inflammatory bowel disease. Clin Nutrition 2012, 15:1-6. 10.1097/MCO.0b013e328357f623.

\section{doi:10.1186/1475-2891-12-145}

Cite this article as: Grunbaum et al:: Dynamics of vitamin D in patients with mild or inactive inflammatory bowel disease and their families. Nutrition Journal 2013 12:145 